\title{
Baseline Corticosterone Peaks in Shorebirds with Maximal Energy Stores for Migration: A General Preparatory Mechanism for Rapid Behavioral and Metabolic Transitions?
}

\author{
Theunis Piersma, ${ }^{*} \dagger$ Jeroen Reneerkens, ${ }^{*} \dagger ’$ and Marilyn Ramenofsky \\ *N etherlands Institute for Sea Research (NIOZ), P.O. Box 59, 1790 AB Den Burg, Texel, The N etherlands; †Centre for \\ Ecological and Evolutionary Studies, University of Groningen, P.O. Box 14, 9750 AA Haren, The N etherlands; \\ and $¥$ D epartment of Zoology, U niversity of W ashington, Box 351800, Seattle, W ashington 98195
}

Accepted July 24,2000

In captive red knots (C alidris canutus, Scolopacidae) showing a regulated body mass increase of $50 \%$ related to their migration from temperate staging sites to tundra breeding grounds, plasma corticosterone concentrations increased from less than $10 \mathrm{ng} \cdot \mathrm{ml}^{-1}$ to levels as high as $30 \mathrm{ng} \cdot \mathrm{ml}^{-1}$ when the energy storage for migration was complete. These birds did not fly, but concentrations dropped to very low levels ( $<5 \mathrm{ng}$. $\mathrm{ml}^{-1}$ ) as soon as the birds started their voluntary fasts to the low body masses preceding the early wing and body molts normally occurring after an unsuccessful breeding season. As the elevated levels of corticosterone are associated with stable body mass rather than with the preceding increase or subsequent decrease, it is suggested that a major role of corticosterone during the final stages just before departure may be to prepare birds for long-distance flights. Birds heading into the Arctic to breed face potentially arduous flights into unpredictable environmental and social conditions. Activation of the hypothalamic-pituitary-adrenal axis, as measured by elevated levels of corticosterone, may induce the suite of behavioral and metabolic changes necessary to negotiate these challenges successfully.

(c) 2000 Academic Press

Key Words: corticosterone; environmental unpredictability; migration; shorebirds; stress.
The preparation for, and the execution of, longdistance flights in migrating birds involves a large number of physiological changes (Ramenofsky, 1990; Wingfield et al., 1990; Jenni and Jenni-Eiermann, 1998; Piersma, 1998). The glucocorticosteroid hormone, corticosterone, is thought to be important in the physiological orchestration of avian migration because of the identified elevated level of activity of the avian adrenal gland either prior to (John, 1965; Naik and George, 1963) or during (Peczely, 1976) migration. Shorebird species (Scolopacidae) display temporary elevations of this glucocorticoid, at least during northward migration and immediately after arrival from flights of several 1000 km (O'Reilly and Wingfield, 1995; Ramenofsky et al., 1995; Tsipoura et al., 1999). Long-term captive red knots (Calidris canutus) that maintain natural mass and molt cycles, even though they are unable to fly beyond the boundaries of the aviaries, also show elevated levels of plasma corticosterone during both northward and southward migration, periods which are indicated by peaks in body mass (Piersma and Ramenofsky, 1998). Furthermore, elevated levels of baseline corticosterone have been found in several passerines during the migration period (Romero et al., 1997; Holberton, 1999; Ramenofsky et al., 1999), but not consistently across species or seasons (Schwabl et al., 1991; Gwinner et al., 1992). 
Even though there are several indications, based on correlations between adrenal gland activity and migratory period, that corticosterone may play a vital role in migration, the function of the glucocorticoids or even the timing of these effects remains unclear. Although often discussed in singular terms, migration is really made up of a sequence of distinct life cycle "substages" (Ens et al., 1994; Jacobs and Wingfield, 2000). In the course of any substantial migration event, migratory birds (1) physiologically prepare for the flight (feed, gain mass, and perhaps molt), (2) become aphagic and make decisions about exact timing of departure, (3) depart and fly, and (4) arrive at their destination. Such stages can even be recognized in migrants held in the laboratory (e.g., Gwinner, 1990; Klaassen and Biebach, 1994). It is with respect to corticosterone levels during the various substages that the literature falls short. During which substage(s) is corticosterone elevated and which role might it then play?

Dallman et al. (1993) and Leibowitz et al. (1984) have shown that administration of corticosterone to adrenalectomized rats has a permissive effect on feeding, but this is at basal levels of corticosterone. The literature on birds is controversial. In some cases administration of corticosterone seems to increase foraging, yet in others such an effect is unclear (Nagra et al., 1963; Wingfield and Silverin, 1986; Gross et al., 1980; Kafri et al., 1988; Gray et al., 1990). A clear dichotomy was found by Astheimer et al. (1992) who studied Gambel's white-crowned sparrows (Zonotrichia leucophrys gambelii). Implanted corticosterone had no effect on feeding intensity in well-fed birds; only after a 24-h fast did corticosterone implantation enhance feeding activity. However, the ecological context of this experiment is very different from that experienced by a migratory bird fattening for migration, and the relevance of the findings of Astheimer et al. (1992) remains unclear for long-distance migrants.

Long-distance flying birds catabolize stored fat and the proteinaceous tissue of most of their organs (Battley et al., 2000). Corticosterone may play a role in mobilizing these fuels by directing catabolic activities associated with gluconeogenesis or the retrieval of glucose from protein and amino acids (Holmes and Philips, 1976; McMahon et al., 1988). Few studies have addressed this issue. For actively exercising homing pigeons (Columba livia), Haase et al. (1986) have shown that corticosterone increases with duration of flight.

This study on captive red knots (C. canutus; Scolopacidae) aims to fill a gap in that it describes the relationship between endogenous levels of corticosterone and three distinct substages that are part of a complete long-distance migration event: (1) feeding + fattening (mass gain), (2) ready for takeoff + waiting for good departure conditions (level mass), and (3) "flight" (mass loss). Even in small outdoor aviaries red knots in the north temperate zone maintain cycles of molts, plumages, and body mass (Piersma et al., 1995). In these cycles the preparations for the northward migration to the tundra breeding grounds can be recognized (Weber and Piersma, 1996; Piersma and Ramenofsky, 1998). In late May-early June the birds show sharply elevated body mass levels. This is associated with an apparent urge to migrate northward, as during the period of stable peak mass birds show strongly increased frequencies of restlessness (including flights) and even song and sexual harassments of flock mates (both of which are also observed in the field; Piersma et al., 1991). These behaviors stop at the onset of the voluntary mass losses that involve decreases in the sizes of organ tissue and the amount of fat (Weber and Piersma, 1996). From April to July 1996 plasma samples were collected at weekly intervals to examine how baseline levels of corticosterone change during various substages of the restrained migration shown by captive red knots.

\section{METHODS}

Birds and aviaries. All experimental birds were captured during darkness with mistnets on Normerven, Wieringen, a high-tide roost in the western Dutch Wadden Sea. One bird was caught there on 26 October 1994, 12 were caught on 6 November 1994, and another bird was caught on 27 October 1995. Given the time and place of capture, all birds belonged to the islandica subspecies that breeds on high arctic tundra in northern Greenland and northeast Canada and spends the nonbreeding season (August through April) in the large estuaries of western Europe (Davidson and Wilson, 1992). Thirteen of the 14 experimental red knots had been held in captivity for more 
than 1 year before this study, such that acclimatization to captive conditions was assured (cf. Piersma and Ramenofsky, 1998).

Birds were individually marked with numbered aluminum bands around the right tibia, and seven each were randomly assigned to two separate aviaries within 1 month of capture. Based on dissection of a single bird that died after the experiment and poststudy molecular assays using small blood samples of the remaining 13 (Baker et al., 1999), 5 of the 14 birds were female. One aviary contained four females and three males, and another aviary contained one female and six males. The outdoor aviaries measured 2 by $4 \mathrm{~m}$, with a height of $2 \mathrm{~m}$. Rubber-coated concrete floors that occupied $3 / 4$ of the surface of the aviaries were kept wet with seawater sprinklers along the edges. The floors were cleaned and disinfected weekly. The remaining $1 / 4$ of their surfaces contained shallow basins with Wadden Sea sand and running seawater (see Piersma and Ramenofsky, 1998, Fig. 3b for a photograph). Each aviary contained a small freshwater basin for drinking and bathing. The red knots were fed protein-rich trout food pellets ad lib. This is an apparently attractive alternative to their normal shellfish diet (Piersma et al., 1993).

Once per week the birds were taken out of the aviaries for a few hours and screened for occurrence of injuries, molt, and body mass. Body mass was measured on an electronic balance to the nearest gram, and the extent of breeding plumage was scored on a 1-7 scale (a 1 indicating a full gray winter plumage, a 2 indicating a trace of breeding plumage, a 3 indicating a quarter breeding plumage, up to a 7 indicating a full rusty-red breeding plumage). During the absence of the birds the aviaries were cleaned and disinfected and the food trays refilled.

Blood sampling. From 15 May to 10 July 1996 blood samples were taken once per week on the day of bird screening and aviary cleaning. Birds were not disturbed before they were captured in the aviary, which occurred between $9.00 \mathrm{~h}$ and $11.00 \mathrm{~h}$ to circumvent problems that daily rhythms in corticosterone levels might give (cf. Marra et al., 1995; Ramenofsky et al., 1999). For every individual we carefully timed the interval between the moment that we entered the aviary and the completion of bleeding. Birds were bled from the wing vein into heparinized capillaries, collecting 200-300 $\mu \mathrm{l}$ of blood on each occasion. Samples were centrifuged at $6900 \mathrm{~g}$ for 15 min within $1-2 \mathrm{~h}$ after bleeding. Plasma was aspirated from each sample and stored (with $10 \mu \mathrm{l}$ of a $3 \%$ solution of $\beta$-propriolactone to satisfy United States import regulations) at $-80^{\circ}$ until transported frozen to Seattle.

Radioimmuno assay (RIA). Concentration of corticosterone was determined by specific RIA according to the procedures described by Wingfield and Farner (1975), but with the modifications of Ball and Wingfield (1987) and Wingfield et al. (1992). Plasma was thawed and $20 \mu \mathrm{l}$ of each sample of plasma was pipetted into glass centrifuge tubes to which $280 \mu \mathrm{l}$ distilled water was added. A total of $2000 \mathrm{cpm}$ $\left[{ }^{3} \mathrm{H}\right]$ corticosterone (NEN; NET-399) was added to each sample and allowed to equilibrate overnight at $4^{\circ}$. The lipid fraction in each sample was extracted with $4 \mathrm{ml}$ of distilled dichloromethane which was then dried under nitrogen gas at $37^{\circ}$. The dried extracts were resuspended in $550 \mu \mathrm{l}$ phosphate-buffered saline with $0.1 \%$ gelatin. Duplicate subsamples of $200 \mu \mathrm{l}$ were measured by RIA. The remaining $100 \mu \mathrm{l}$ was pipetted into a glass vial to which we added $4.5 \mathrm{ml}$ scintillation fluid. CPM from each vial were corrected for dilution and provided an estimate of percentage recovery of steroid following extraction for each sample. Concentration of corticosterone was determined from a standard curve that ranged from 7.8 to $2000 \mathrm{pg} / \mathrm{ml}$ and each sample was adjusted for percentage of recovery. All samples could be analyzed in a single assay. The percentages of recovery ranged from 70 to $100 \%$.

Statistics. Having verified that the data obeyed the normality criterion, individual and time effects on corticosterone level were analyzed using standard analysis of variance (ANOVA).

\section{RESULTS}

During 1996, experimental red knots showed the expected slow increase in body mass from late April to late May (Fig. 1A). The total increase equals about 50\% of the initial body mass. A period of stable high mass was documented from late May to early June followed by a rapid drop in mass. There were no detectable sexor aviary-related differences in the body mass curves, although all individuals (except the one that was captured in late 1995) reached slightly higher peak masses 

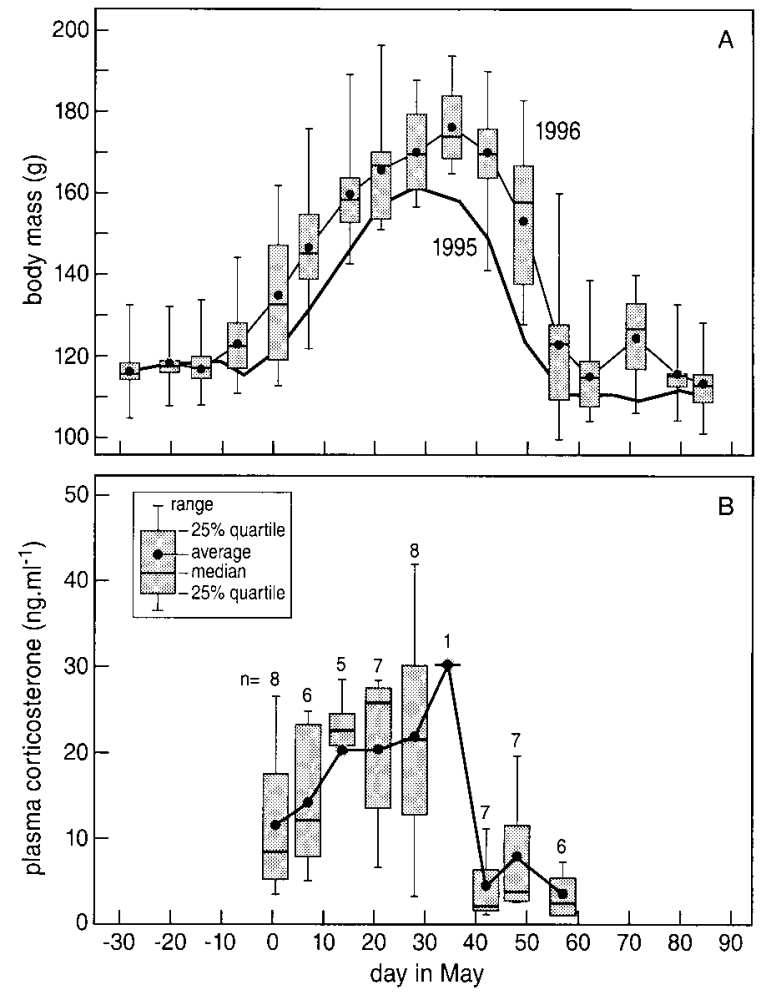

FIG. 1. (A) Seasonal change in average body mass of the 14 experimental red knots in 1996. For comparison, the average body mass trajectory for 13 of the 14 birds in 1995 is given by the thick line. (B) Plasma corticosterone concentrations from all 14 red knots as measured in plasma samples collected within 4 min after cage entry; $n$ values are indicated above the range bars.

in 1996 than in 1995. This slow increase in the height of the spring mass peak over the first few years in captivity appears typical for captive red knots belonging to the islandica subspecies (Piersma et al., 1995; Piersma and Ramenofsky, 1998).

Following entry into the aviary, plasma levels of corticosterone rose after $4 \mathrm{~min}$ of capture and handling (Fig. 2). The timing and the rate of the increase is typical of the stress response to capture and handling described in many other species (Wingfield, 1994). In the statistical analyses that follow, only plasma samples that were collected within the first $4 \mathrm{~min}$ after entry of the aviaries are used and defined as baseline levels. As there were no detectable differences in plasma corticosterone concentration among the 14 individuals in the entire sample (ANOVA, $F_{13,91}=$ $0.983, P=0.475)$, it was justified to analyze for other effects without taking individual variation into ac- count. A further analysis of variance showed that the variation in corticosterone concentrations between dates was larger than the variation within dates $\left(F_{8,46}=3.430, P=0.004\right)$. Plasma corticosterone peaked at about $30 \mathrm{ng} \cdot \mathrm{ml}^{-1}$ in late May and early June, i.e., during the period of stable peak body masses (Fig. 1B). The peak level is roughly three times the level during the beginning of the mass increase (ca. $10 \mathrm{ng} \cdot \mathrm{ml}^{-1}$ ).

A plot of individual baseline corticosterone on the rate of body mass change during the preceding week (Fig. 3) illustrates that, during periods of mass loss, corticosterone levels were even lower than $5 \mathrm{ng} \cdot \mathrm{ml}^{-1}$. Furthermore, corticosterone was highest when individual body mass values were high and stable (Fig. 3A; ANOVA, $\left.F_{1,36}=6.380, P=0.016\right)$. A multivariate analysis including sex (Fig. 3B) and the interaction between phase and sex showed no effects of either of these two factors $\left(F_{1,34}\right.$ ratios of 1.500 and 0.712 and $P$ values of 0.229 and 0.405 , respectively).

The captive birds were rather asynchronous in the timing of their body mass decreases. Thus, the patterns of body mass and corticosterone levels are illustrated in the four individuals for which there are reasonably complete series of baseline samples (Fig. 4). In all four cases plasma corticosterone peaked during the period of stable peak mass, rising to the high values

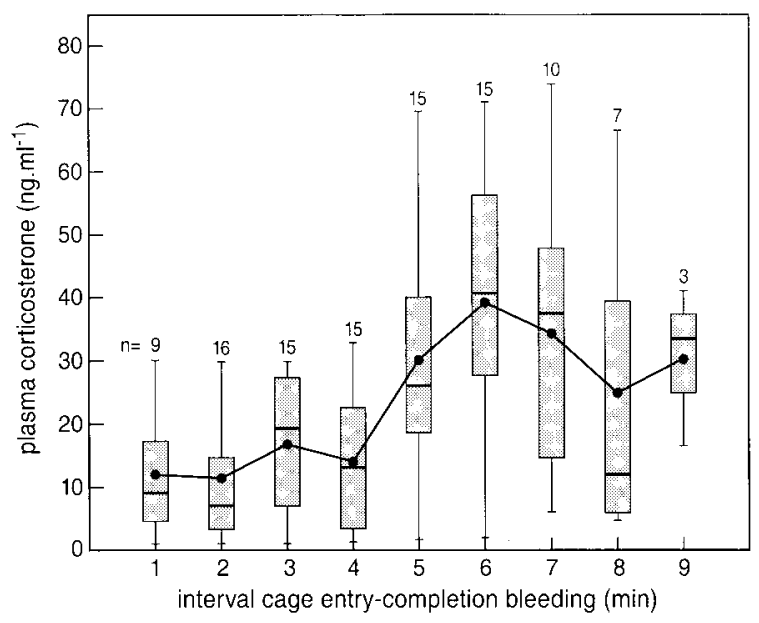

FIG. 2. Increase in plasma corticosterone levels of red knots as a function of the time between entry of the aviaries and completion of bleeding to the nearest minute. Note that lengths of intervals were random with respect to time of year and individual. The data are presented as box plots as explained in Fig. 1B; $n$ values are indicated above the range bars. 


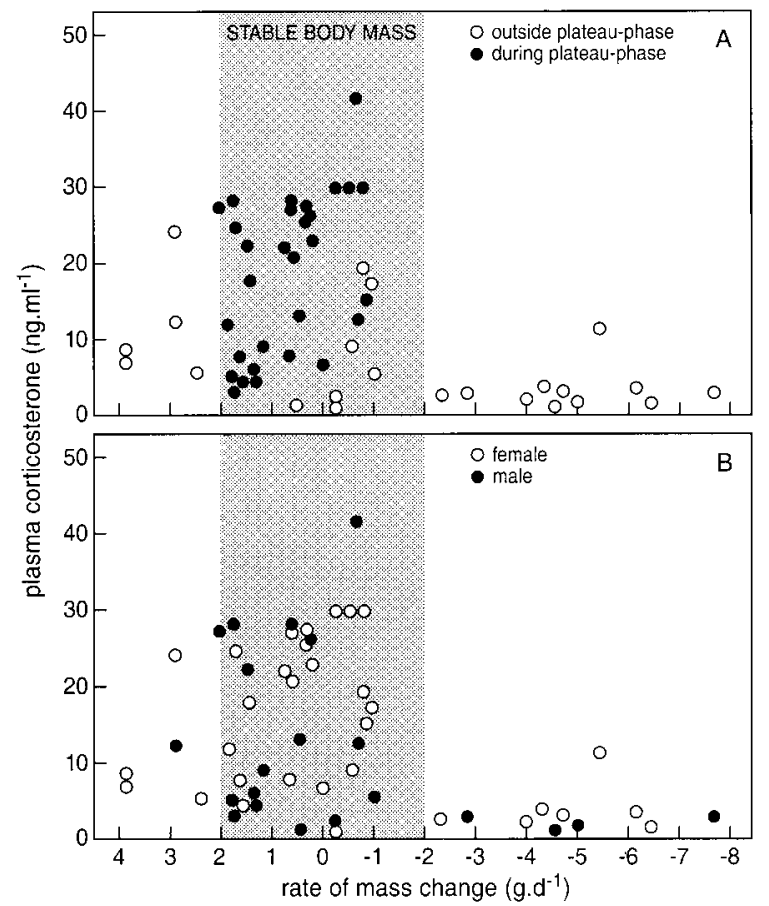

FIG. 3. Plasma corticosterone levels as a function of the average daily mass change over the 7 days preceding the day of bleeding in captive red knots, plotted separately for individuals during and outside the plateau phase in body mass (A) and separately for sex (B). The plateau phase is defined as the period after 25 May when individual body mass values are larger than $140 \mathrm{~g}$.

only after peak mass had been reached and dropping to particularly low values as soon as body mass dropped. Figure 4 suggests that there are no relationships between either body mass or corticosterone concentrations and timing of the molt into a breeding plumage or completeness of this plumage change.

\section{DISCUSSION}

High corticosterone concentrations occur only at a time when captive red knots have maximum fuel stores. The findings thus focus on the substage of the long-distance migration event during which the birds are fully "fueled up." The birds may then be ready for takeoff, although perhaps still undergoing internal reorganization not reflected by changes in body mass (Piersma, 1998). The importance of distinguishing between the various substages of a migratory event has been overlooked in the literature thus far (Romero et al., 1997; Piersma and Ramenofsky, 1998; Holberton, 1999).

The disassociation between elevations of corticosterone level and body mass changes suggests that corticosterone has little to do with energy management. To develop the hypothesis about the particular role of corticosterone in the context of long-distance migration, it is apt to first consider what long-distance migrant shorebirds do when they have accumulated sufficient nutritional stores to fly directly to the breeding grounds. In the captive red knots this phase commences once they have reached stable peak body mass levels but are unable to fly off due to their confinement. It is unlikely that the elevated levels before departure directly reflect adjustments to the breeding period per se (cf. Romero et al., 1997). In this case levels would have been predicted to remain high even during mass loss. In fact, baseline corticosterone levels are rather low during the breeding season in higharctic breeding red knots (J. Reneerkens and R. I. G. Morrison, unpublished data).

In nature, the success of such long migratory flights may depend to a large extent on the environmental conditions during takeoff and en route and on the number and quality of the migratory flock mates (Piersma et al., 1990). Also, being ready to depart means that birds must make a transition from having regular routines in relatively benign environments (Piersma et al., 1994) to a flight lasting several days to the tundra breeding grounds where environmental conditions are highly unpredictable (Green et al., 1977; Myers and Pitelka, 1979; Piersma and Morrison, 1994). Additionally, the birds may face severe competition for suitable territories and mates immediately after arrival (Whitfield and Brade, 1991).

Shorebirds that are ready to depart for the breeding grounds must be able to integrate many internal and external cues from the physical and social environments to determine when to fly. The required level of "adaptive anxiety" in making the decision to take off may thus be much higher than under normal conditions and may represent an upregulation of processes that have been formerly associated with stress (Wingfield et al., 1997). Here we propose that the hypothalamic-pituitary-adrenal axis is functionally activated to enable the birds to appropriately face the challenges imposed by the unpredictable environmen- 

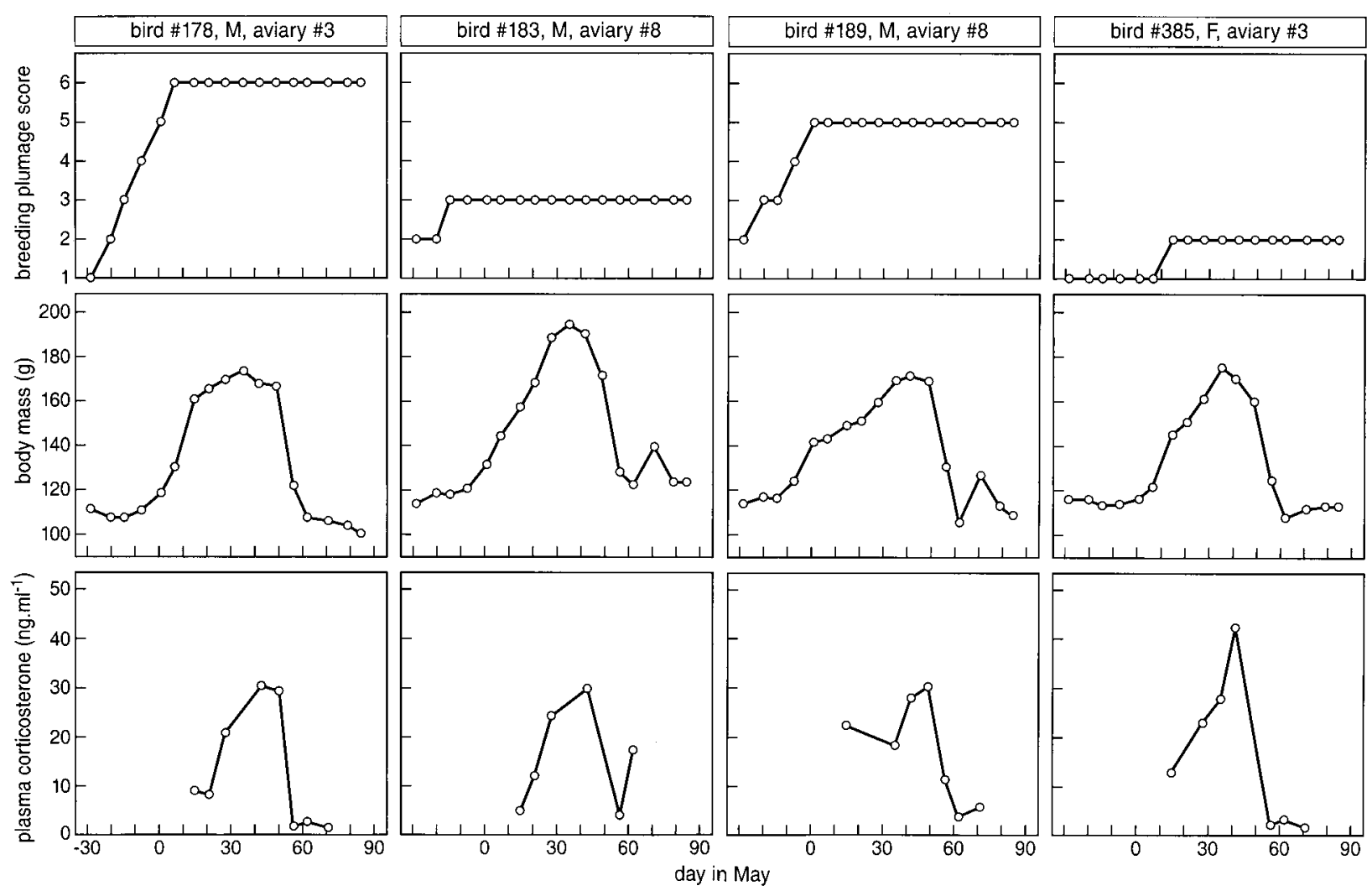

FIG. 4. Comparison of the seasonal changes in plumage score, body mass, and plasma corticosterone levels in 4 of the 14 captive red knots in April-July 1996. Plumage scores indicate extent of breeding plumage, with score 1 representing full winter plumage and score 6 representing almost full breeding plumage (trace of winter plumage). These 4 birds were selected on the basis of the availability of (almost) weekly plasma samples collected within 4 min after cage entry.

tal and social conditions resulting from long-distance flights toward the breeding grounds (cf. Astheimer et al., 1995).

This hypothesis can address what Ramenofsky et al. (1995) called the "confusing" observation of high corticosterone levels in bar-tailed godwits (Limosa lapponica) that were ready to depart for a 5000-km-long flight from the Dutch Wadden Sea to the Siberian breeding grounds (observations that have since been substantiated; M. Landys, M. Ramenofsky, T. Piersma, and J. Jukema, unpublished data). Comparison of maximal levels of corticosterone at two sites during northward migration of western sandpipers (Calidris mauri) identified a significant elevation at the more northerly location (O'Reilly, 1995; O'Reilly and Wingfield, 1995). At this site, birds had greater distances to cover before reaching the tundra breeding grounds, and body mass and fat score were greater than at the more southerly location. This suggest that these birds were preparing for the longer flights and potentially for the more uncertain environmental circumstances upon arrival. Although the data on godwits and sandpipers were collected in the field from birds actively engaged in migratory flights, the finding of elevated body mass and corticosterone are intriguingly reminiscent of the captive red knots. That the captive birds immediately responded with low corticosterone levels as soon as their body masses started to drop may be interpreted as reflecting the fact that by then they had given up the long northward flight. Indeed, the birds are forced to remain in the confines of the aviaries and will start the molt of contour and flight feathers within a couple of weeks, as is the habit of individuals that "opt out," skip a breeding season, and remain on temperate staging or wintering areas (T. Piersma, unpublished data).

Our results are also in line with recent correlational data on corticosterone in relation to the dispersal of 
birds. Based on the finding that free-living juvenile screech owls (Asio kennicottii) disperse at the time that captive juveniles show high levels of corticosterone in combination with high locomotor activity, Belthoff and Dufty (1998) proposed that when a growing individual has stored enough fat, elevated plasma corticosterone concentrations induce the locomotor activity required for dispersion. Indeed, Bruener et al. (1998) demonstrated an immediate influence upon locomotor activity following the noninvasive administration of moderate doses of corticosterone in fully grown Gambel's white-crowned sparrows. Similarly, in American kestrels (Falco sparverius), juveniles showed significantly increased circulating corticosterone when they were ready to leave the nest (Heath, 1997). On the basis of behavioral observations in a field experiment with willow tits (Parus montanus), Silverin (1997) proposed that corticosterone redirects juveniles from (the presumably preferred) establishment in a flock to dispersal into unpredictable situations where survival may be lower.

In the latter cases, as well as with respect to the fattened captive knots, the trigger for the elevation of corticosterone levels is unknown. The effects, however, may be behavioral (as described previously for correlational data) and perhaps metabolic (preparing for mobilization of energy stores and/or influencing organ remodeling prior to migration flight). We thus propose that in birds corticosterone fulfills particular and rather specific roles in inducing the suite of psychological, behavioral, and metabolic changes that are necessary for successful movements into the unknown.

\section{ACKNOWLEDGMENTS}

We thank Ciska Raaijmakers, Anita Koolhaas, Anne Dekinga, Pieter Honkoop, Piet Duiven, and Bernard Spaans for much practical help during this study, Theo Mulder for hospitality during the nights at Normerven, Annette D. Greenslade and Allan J. Baker for molecularly sexing the experimental birds, and Meta Landys, John C. Wingfield, and Jaap M. Koolhaas for stimulating feedback and comments on drafts. This research was supported by a PIONIER grant to T.P. from the Netherlands Organization for Scientific Research (NWO) and was carried out under the auspices of the DEC (Animal Experiment Committee) of the Dutch Royal Academy of Sciences (KNAW). J.R. received a travel grant from the Schuurman
Schimmel-Van Outeren Stichting. M.R. was supported by a University of Washington Graduate School Research Fellowship. This is NIOZ publication 3353.

\section{REFERENCES}

Astheimer, L. B., Buttemer, W. A., and Wingfield, J. C. (1992). Interactions of corticosterone with feeding, activity and metabolism in passerine birds. Ornis Scand. 23, 355-365.

Astheimer, L. B., Buttemer, W. A., and Wingfield, J. C. (1995). Seasonal and acute changes in adrenocortical responsiveness in an arctic-breeding bird. Horm. Behav. 29, 442-457.

Baker, A. J., Piersma, T., and Greenslade, A. D. (1999). Molecular versus phenotypic sexing in red knots. Condor 101, 997-893.

Ball, G. F., and Wingfield, J. C. (1987). Changes in plasma levels of sex steroids in relation to multiple broodedness and nest site density in male starlings. Physiol. Zool. 60, 191-199.

Battley, P. F., Piersma, T., Dietz, M. W., Tang, S., Dekinga, A., and Hulsman, K. (2000). Empirical evidence for differential organ reductions during trans-oceanic bird flight. Proc. R. Soc. Lond. B 267, 191-195.

Belthoff, J. R., and Dufty, A. M., Jr. (1998). Corticosterone, body condition and locomotor activity: A model for dispersal in screech-owls. Anim. Behav. 55, 405-415.

Breuner, C. W., Greenberg, A. L., and Wingfield, J. C. (1998). Noninvasive corticosterone treatment rapidly increases activity in Gambel's white-crowned sparrows (Zonotrichia leucophrys gambelii). Gen. Comp. Endocrinol. 111, 386-394.

Dallman, M. F., Strack, A. M., Akawa, S. F., Bradbury, M. J., Hanson, E. S., Scribner, K. A., and Smith, M. (1993). Feast and famine: Critical role of glucocorticoids with insulin in daily energy flow. Front. Neuroendocrinol. 14, 303-347.

Davidson, N. C., and Wilson, J. R. (1992). The migration system of European-wintering knots Calidris canutus islandica. Wader Study Group Bull. 64(Suppl.) 39-51.

Ens, B. J., Piersma, T., and Tinbergen, J. M. (1994). “Towards Predictive Models of Bird Migration Schedules: Theoretical and Empirical Bottlenecks." NIOZ Report 1994-1995, Texel.

Gray, J. M., Yarian, D., and Ramenofsky, M. (1990). Corticosterone, foraging behavior, and metabolism in dark-eyed juncos Junco hyemalis. Gen. Comp. Endocrinol. 79, 375-384.

Green, G. H., Greenwood, J. J. D., and Lloyd, C. S. (1977). The influence of snow conditions on the date of breeding in waders in north-east Greenland. J. Zool. Lond. 183, 311-328.

Gross, W. B., Siegel, P. B., and Cubose, R. T. (1980). Some effects of feeding corticosterone to chickens. Poultry Sci. 59, 516-522.

Gwinner, E. (1990). Circannual rhythms in bird migration: Control of temporal patterns and interactions with photoperiod. In "Bird Migration: Physiology and Ecophysiology" (E. Gwinner, Ed.), pp. 257-268. Springer-Verlag, Berlin.

Gwinner, E., Zeman, E., Schwabl-Benzinger, I., Jenni-Eiermann, S., Jenni, L., and Schwabl, H. (1992). Corticosterone levels of passerine birds during migratory flight. Naturwissenschaften 79, 276 278. 
Haase, E., Rees, A., and Harvey, S. (1986). Flight stimulates adrenocortical activity in pigeons (Columba livia). Gen. Comp. Endocrinol. 66, 424-427.

Heath, J. (1997). Corticosterone levels during nest departure of juvenile American Kestrels. Condor 99, 806-811.

Holberton, R. L. (1999). Changes in patterns of corticosterone secretion concurrent with migratory fattening in a neotropical migratory bird. Gen. Comp. Endocrinol. 116, 49-58.

Holmes, W. N., and Philips, J. G. (1976). The adrenal cortex of birds. In "General, Comparative and Clinical Endocrinology of the Adrenal Cortex" (I. Chester-Jones and I. W. Henderson, Eds.), pp. 293-420. Academic Press, New York.

Jacobs, J. D., and Wingfield, J. C. (2000). Endocrine control of lifecycle stages: A constraint on response to the environment? Condor 102, 35-51.

Jenni, L., and Jenni-Eiermann, S. (1998). Fuel supply and metabolic constraints in migrating birds. J. Avian Biol. 29, 521-528.

John, T. M. (1965). A histochemical study of adrenal corticoids in pre and post migratory wagtails Motacilla alba and M. flava. Pavo 4, 9-14.

Kafri, I., Rosebrough, R. W., McMurtry, J. R., and Steele, N. C. (1988). Research note: Corticosterone implants and supplemental dietary ascorbic acid effect on lipid metabolism in broiler chicks. Poultry Sci. 67, 1356-1359.

Klaassen, M., and Biebach, H. (1994). Energetics of fattening and starvation in the long-distance migratory garden warbler, Sylvia borin, during the migration phase. J. Comp. Physiol. B 164, 362-371.

Leibowitz, S. F., Roland, C. R., Hor, L., and Squillari, V. (1984). Noradrenergic feeding via the paraventricular nucleus is dependent upon circulating corticosterone. Physiol. Behav. 32, 857-864.

Marra, P. P., Lampe, K. T., and Telford, B. L. (1995). Plasma corticosterone levels in two species of Zonotrichia sparrows, under captive and free-living conditions. Wilson Bull. 107, 296-305.

McMahon, M., Gerich, J., and Rizza, R. (1988). Effects of glucocorticoids on carbohydrate metabolism. Diabetes/Metabolism Rev. 4, 17-30.

Myers, J. P., and Pitelka, F. (1979). Variations in summer temperature patterns near Barrow, Alaska: Analysis and ecological interpretation. Arct. Alp. Res. 11, 131-144.

Naik, D. V., and George, J. C. (1963). Histochemical demonstration of increased corticoid level in the adrenal of Sturnus roseus (Linnaeus) towards the migratory phase. Pavo 1, 103-105.

Nagra, C. L., Breitenbach, R. P., and Meyer R. K. (1963). Influence of hormones on food intake and lipid deposition in castrated pheasants. Poultry Sci. 42, 770-775.

O'Reilly, K. M. (1995). “Ecological Basis of Endocrine Phenomena: Field Studies of Scolopacidae as Model Systems." Thesis, University of Washington, Seattle.

O'Reilly, K. M., and Wingfield, J. C. (1995). Spring and autumn migration in arctic shorebirds: Same distance, different strategies. Am. Zool. 35, 222-233.

Peczely, P. (1976). Étude circannuelle de la fonction corticosurrenalienne chez les espêces de passereaux migrant et non migrant. Gen. Comp. Endocrinol. 30, 1-11.

Piersma, T. (1998). Phenotypic flexibility during migration: Optimization of organ size contingent on the risks and rewards of fueling and flight? J. Avian Biol. 29, 511-520.
Piersma, T., and Morrison, R. I. G. (1994). Energy expenditure and water turnover of incubating Ruddy Turnstones: High costs under high arctic climatic conditions. Auk 111, 366-376.

Piersma, T., and Ramenofsky, M. (1998). Long-term decreases of corticosterone in captive migrant shorebirds that maintain seasonal mass and moult cycles. J. Avian Biol. 29, 97-104.

Piersma, T., Zwarts, L., and Bruggemann, J. H. (1990). Behavioural aspects of the departure of waders before long-distance flights: Flocking, vocalizations, flight paths and diurnal timing. Ardea 78, 157-184.

Piersma, T., Tulp, I., Verkuil, Y., Wiersma, P., Gudmundsson, G. A., and Lindström, Å. (1991). Arctic sounds on temperate shores: The occurrence of song and ground display in knots Calidris canutus at spring staging sites. Ornis Scand. 22, 404-407.

Piersma, T., Koolhaas, A., and Dekinga, A. (1993). Interactions between stomach structure and diet choice in shorebirds. Auk 110, 552-564.

Piersma, T., Verkuil, Y., and Tulp, I. (1994). Resources for long-distance migration of knots Calidris canutus islandica and C. c. canutus: How broad is the temporal exploitation window of benthic prey in the western and eastern Wadden Sea. Oikos 71, 393-407.

Piersma, T., Cadée, N., and Daan, S. (1995). Seasonality in basal metabolic rate and thermal conductance in a long-distance migrant shorebird, the knot (Calidris canutus). J. Comp. Physiol. B 165, 37-45.

Ramenofsky, M. (1990). Fat storage and fat metabolism in relation to migration. In "Bird Migration: Physiology and Ecophysiology" (E. Gwinner, Ed.), pp. 214-231. Springer-Verlag, Berlin.

Ramenofsky, M., Piersma, T., and Jukema, J. (1995). Plasma corticosterone in bar-tailed godwits at a major stop-over site during spring migration. Condor 97, 580-585.

Ramenofsky, M., Savard, R., and Greenwood, M. R. C. (1999). Seasonal and diel transitions in physiology and behavior in the migratory dark-eyed junco. Comp. Biochem. Physiol. 122A, 385-397.

Romero, L. M., Ramenofsky, M., and Wingfield, J. C. (1997). Season and migration alters the corticosterone response to capture and handling in an arctic migrant, the White-crowned Sparrow (Zonotrichia leucophrys gambelii). Comp. Biochem. Physiol. C 116, 171-177.

Schwabl, H., Bairlein, F., and Gwinner, E. (1991). Basal and stressinduced corticosterone levels of garden warblers, Sylvia borin, during migration. J. Comp. Physiol. B 161, 576-580.

Silverin, B. (1997). The stress response and autumn dispersal behaviour in willow tits. Anim. Behav. 53, 451-459.

Tsipoura, N., Scanes, C. G., and Burger, J. (1999). Corticosterone and growth hormone levels in shorebirds during spring and fall migration stopover. J. Exp. Zool. 284, 645-651.

Weber, T. P., and Piersma, T. (1996). Basal metabolic rate and the mass of tissues differing in metabolic scope: Migration-related covariation between individual knots Calidris canutus. J. Avian Biol. 27, 215-224.

Whitfield, D. P., and Brade, J. J. (1991). The breeding behaviour of the knot Calidris canutus. Ibis 133, 246-255.

Wingfield, J. C. (1994). Modulation of the adrenocortical response to stress in birds. In "Perspectives in Comparative Endocrinology" (K. G. Davey, R. E. Peter, and S. S. Tobe, Eds.), pp. 520-528. National Research Council Canada, Ottawa. 
Wingfield, J. C., and Farner, D. S. (1975). The determination of five steroids in avian plasma by radioimmunoassay and competitive protein binding. Steroids 26, 311-327.

Wingfield, J. C., and Farner, D. S. (1993). Endocrinology of reproduction in wild species. In "Avian Biology" (D. S. Farner, J. R. King, and K. C. Parkes, Eds.), Vol. IX, pp.163-327. Academic Press, London.

Wingfield, J. C., and Ramenofsky, M. (1997). Corticosterone and facultative dispersal in response to unpredictable events. Ardea 85, 155-166.

Wingfield, J. C., and Ramenofsky, M. (1999). Hormones and the behavioral ecology of stress. In "Stress Physiology" (P. H. M. Balm, Ed.), pp. 1-51. Sheffield Univ. Press, Sheffield, UK.

Wingfield, J. C., and Silverin, B. (1986). Effects of corticosterone on territorial behavior of free-living male song sparrows Melospiza melodia. Horm. Behav. 20, 405-417.

Wingfield, P. C., Schwabl, H., and Mattocks, P. W., Jr. (1990). Endocrine mechanisms of migration. In "Bird Migration: Physiology and Ecophysiology" (E. Gwinner, Ed.), pp. 232-256. SpringerVerlag, Berlin.

Wingfield, J. C., Vleck, C. M., and Moore, M. C. (1992). Seasonal changes in the adrenocortical response to stress in birds of the Sonoran desert. J. Exp. Zool. 264, 419-428.

Wingfield, J. C., Breuner, C., and Jacobs, J. (1997). Corticosterone and behavioral responses to unpredictable events. In "Perspectives in Avian Endocrinology" (S. Harvey and R. J. Etches, Eds.), pp. 267-278. Journal of Endocrinology Ltd., Bristol.

\section{GENERAL AND COMPARATIVE ENDOCRINOLOGY}

Published monthly by Acadenic Press, 6277 Sca Harbor Drive, Orlando, FL 32887-4900. Number of issues published annually: 12. Editors: Dr. F. L. Moure, Department of Zoology, Orequn State University, Corvallis, OR 97331-2914; and Dr. I.W. Henderson, Institute of Endocrinology, Department of Animal and Plant Sciences, Wester Bank, University of Shetlield, Sheflield S $102 \mathrm{TN}$, United Kingdiom.

Owned by Acadenic Press, 525 B Street, Suite 190() , San Diego, CA y2101-4495. Known bondholders, mortgagees, and other security holders owning or holding 1 percent or more of total amount of bonds, mortgages, and other securities: None.

Paragraphs 2 and 3 include, in cases where the stockholder or security holder appears upon the books of the company as trustee or in any other fiduciary relation, the name of the person or corporation for whom such trustec is acting also the stalements in the two paragraphs show the affiant's lull knowledge and belief as to the circumstances ani conditions under which stockholders and security holders who do not appear upon the books of the company as trustees, hold stock and securities in a capacity other than that of a bona fide owner Names and addresses of trustees, ho who are alosses of indivitios or other individuals are equivalent to 1 percent or more of the total amount of the stock or securities of the publishing individutis are equivalent to I percent or more of the total amount of the stock or securities of the publishing
corporation. corporation.

Total no. copies printed: average no. copies each issue during preceding 12 months: 1172; single issue nearest to filing date: 918 . Paid circulation (a) to term subseribers by mail, carrier delivery, or by other means: average no. copies cach issue during preceding 12 months: 364 ; single issue nearest to filing date: 317 . (b) Sales through agents, ncws dealcrs, or otherwise: average no, copjes each issue during preceding 12 months: 216 ; single issuc nearest to liling date: 204 . Free distribution (a) by mail: average no. copies each issue during preceding 12 months: 42 ; single issue nearest to liling date: 42 . (b) Outside the mail: average no. copies each issue during preceding 12 months: 35 single issue nearest io filing date: 35 . Total no, of copies distributed: average no. copies each isste during preceding 12 months: 657; single issue nearest to filing date: 598 . Percent paid and/or requested circulation: average percent each issue during preceding 12 months: $88 \%$; single issue nearest to filing date: $87 \%$.

(Signed) Stephanie Smith, Asst. Manager, Journal Business Otfice 